\title{
POSSIBLE EFFECTS OF CORONAVURUS INFECTION (COVID-19) ON THE CARDIOVASCULAR SYSTEM
}

Larina VN $₫$, Golovko MG, Larin VG

Pirogov Russian National Research Medical University, Moscow, Russia

Acute viral respiratory infections can increase the risk of progression of a pre-existing condition, including a cardiovascular pathology. Life-threatening complications of Coronavirus disease 2019 (COVID-19) caused by severe acute respiratory syndrome coronavirus 2 (SARS-CoV-2) necessitate research into the cardiovascular effects of COVID-19 crucial for developing adequate treatment strategy for infected patients, especially those of advanced age. This article reviews the literature on the clinical and functional characteristics of patients with COVID-19, including those with poor outcomes. The article looks at the pathophysiological processes occurring in the cardiovascular system in the setting of SARS-CoV-2 infection, risk factors and death predictors. It also discusses continuation of therapy with angiotensin-converting enzyme inhibitors and angiotensin II receptor blockers in patients with COVID-19.

Keywords: coronavirus, cardiovascular diseases, infection, severe acute respiratory syndrome, coronavirus infection 2019, angiotensin-converting enzyme, SARS-CoV-2, COVID-19

Acknowledgements: the authors thank Gennady V. Poryadin, Professor at the Department of Pathophysiology and Clinical Pathophysiology (the Faculty of General Medicine, Pirogov Russian National Research Medical University), DMSc and the correspondent member of RAS, for his invaluable critical comments on this paper.

Author contribution: Larina VN conceived and planned the study, analyzed the literature, interpreted the literature data, and revised the manuscript; Golovko MG and Larin VG planned the study, analyzed the literature, interpreted the literature data, and wrote the draft of the manuscript.

$\triangle$ Correspondence should be addressed: Vera N. Larina Ostrovityanova, 1, Moscow, 117997; larinav@mail.ru

Received: 03.04.2020 Accepted: 17.04.2020 Published online: 18.04.2020

DOI: $10.24075 /$ brsmu.2020.020

\section{ВЛИЯНИЕ КОРОНАВИРУСНОЙ ИНФЕКЦИИ (COVID-19) НА СЕРДЕЧНО-СОСУДИСТУЮ СИСТЕМУ}

\author{
В. Н. Ларина $\bowtie$, М. Г. Головко, В. Г. Ларин
}

Российский национальный исследовательский медицинский университет имени Н. И. Пирогова, Москва, Россия

\begin{abstract}
Острые вирусные инфекции дыхательных путей могут увеличить вероятность прогрессирования имеющейся сопутствующей патологии, в том числе сердечно-сосудистого происхождения. Появление жизнеугрожающих осложнений на фоне коронавируса 2 (severe acute respiratory syndrome coronavirus 2, или SARS-CoV-2), вызывающего коронавирусную болезнь 2019 (Coronavirus disease 2019, или COVID-19), обусловливает необходимость изучения кардиоваскулярных эффектов COVID-19 с целью оказания рациональной медицинской помощи пациентам, особенно старшего возраста. В статье представлен обзор литературных данных, посвященных анализу клинико-функциональных особенностей пациентов с COVID-19, в том числе имевших неблагоприятный прогноз. Уделено внимание патофизиологическим особенностям, происходящим на фоне инфекционного процесса в сердечно-сосудистой системе, факторам риска и предикторам летальности при COVID-19. Обсуждается вопрос о возможности продолжения приема ингибиторов ангиотензин-превращающего фермента или антагонистов рецепторов ангиотензина II большинством пациентов с сердечно-сосудистыми заболеваниями и COVID-19.
\end{abstract}

Ключевые слова: коронавирус, сердечно-сосудистые заболевания, инсекция, тяжелый острый респираторный синдром, коронавирусная болезнь 2019, ангиотензин-превращающий фермент, SARS-CoV-2, COVID-19

Благодарности: член-корреспонденту РАН, профессору, д. м. Н., профессору кафедры патофизиологии и клинической патофизиологии лечебного факультета ФГАОУ ВО РНИМУ имени Н. И. Пирогова Минздрава России Геннадию Васильевичу Порядину за ценные критические замечания.

Вклад авторов: В. Н. Ларина - разработка концепции, планирование исследования, анализ литературы, интерпретация данных, написание текста; М. Г. Головко и В. Г. Ларин — планирование исследования, анализ литературы, интерпретация данных, подготовка черновика рукописи.

Для корреспонденции: Вера Николаевна Ларина ул. Островитянова, д. 1, г. Москва, 117997; larinav@mail.ru

Статья получена: 03.04.2020 Статья принята к печати: 17.04.2020 Опубликована онлайн: 18.04.2020

DOI: $10.24075 /$ vrgmu.2020.020

Coronaviruses (CoVs) are a family of positive-sense singlestranded RNA viruses organized into two subfamilies and as of January 2020, numbering 40 different species. CoVs infect animals and humans and are capable of rapid mutation and genetic recombination. CoVs owe their name to their appearance: their spike-like projections resemble the sun's corona. The spikes allow the virus to penetrate the cell membrane by mimicking the molecules recognized by the transmembrane receptors. Once the receptor has bound to the "impostor" molecule, the virus pushes it into the cell and the viral RNA gets inside.

Acute respiratory infections, such as influenza, respiratory syncytial virus infection and bacterial pneumonia, are widely acknowledged as triggers for cardiovascular diseases (CVD); in turn, pre-existing CVD are associated with other comorbid conditions and can increase the risk of inflammation or aggravate its progression.

The outbreak of the novel coronavirus disease 2019 (COVID-19) caused by the severe acute respiratory syndrome coronavirus 2 (SARS-CoV-2) has rapidly escalated into a pandemic; the majority of the infected patients are reported to have CVD [1]

The prospective cohort observational ARIC (atherosclerosis risk in communities) study has demonstrated that there is a higher risk of coronary heart disease (CHD) and ischemic stroke within up to 90 days after a past infection. The study looked at 1,312 CHD and 712 ischemic stroke cases with a past history of infections within one or two years preceding the cardiovascular event. The mean age of the participants was 75 years; $57.4 \%$ of the patients with $\mathrm{CHD}$ were male, whereas 
$54.1 \%$ of the patients with stroke were female. Of 1,312 individuals with CHD, 119 (9.1\%) had a history of an inpatient infection, whereas 366 (27.9\%) had a history of an outpatient infection. The most common were urinary tract infections (29\%), pneumonia or respiratory infections (27\%), skin /subcutaneous infections (11\%), and blood infections (8\%). Inpatient infections remained a stronger trigger of cardiovascular events throughout the entire follow-up period (day $14 \mathrm{OR}=12.83$, day $30 \mathrm{OR}=8.39$, day $42 \mathrm{OR}=6.24$, day $90 \mathrm{OR}=4.48$ ) than outpatient infections $(p<0.05)$. Therefore, hospitalized patients with an inpatient infection should be closely monitored in order to take timely measures to prevent CHD or stroke [2].

In light of this, pathophysiological processes triggered by coronavirus infections in the cardiovascular system certainly pose a great interest. Since our knowledge of the mechanisms underlying COVID-19 effects is scarce yet, the analysis of data collected during the outbreaks of viral pneumonia and MERS (Middle East respiratory syndrome coronavirus, MERS-CoV), as well as seasonal influenza, will provide a better understanding of how coronaviruses exert their effects on the cardiovascular system. This has important implications for the development of comprehensive strategies for the timely management of infected advanced-age patients with CVD.

\section{Effects of coronavirus on human organism}

Coronaviruses get their name from the crown-like spikes on their surface. These viruses are members of the Coronaviridae subfamily clustered into 4 phylogenetic groups: $\alpha, \beta, \gamma$, and $\delta$ CoVs. Only $\alpha$ and $\beta$ CoVs can cause infection in humans. Coronaviruses have 4 main structural proteins: the spike protein (S), which ensures attachment to the host cell receptor and subsequent fusion with the cell membrane, the nucleocapsid protein $(N)$, the membrane protein $(M)$, and the envelope protein $(E)$.

Human coronaviruses (HCoVs) were discovered in 1965 when the first $\mathrm{HCoV}$ was isolated from the culture of human embryo tracheal tissue. By 2003, two types of HCoVs had been identified: HCoV-229E and HCoV-OC43.

Today, 7 different CoV strains are known to infect humans, including HCoV-229E, HCoV-NL63, HCoV-OC43, and HCoV$\mathrm{HKU}$ that normally cause self-resolving symptoms. The virus can also cause severe acute respiratory syndrome (SARS), Middle East respiratory syndrome (MERS) and fatal acute respiratory syndrome resulting from SARS-CoV-2 infection.

\section{Endemicity of coronavirus}

Four types of HCoVs, including $\mathrm{HCoV}-229 \mathrm{E}(\alpha-\mathrm{CoV}), \mathrm{HCoV}-$ NL63 $(\alpha-\mathrm{CoV})$, HCoV-OC43 ( $\beta$-CoV), and HCoV-HKU1 $(\beta-\mathrm{CoV})$, are endemic to humans and normally cause a mild respiratory infection with self-resolving symptoms, accounting for 15 to $30 \%$ of acute respiratory infections (ARI). As a rule, mild symptoms develop in young patients; in older patients, especially those with cardiovascular or bronchopulmonary pathology, the infection can provoke hospitalization and require emergency care [3].

\section{Severe acute respiratory syndrome caused by coronavirus}

The first SARS-CoV outbreak occurred in Guangdong province, South China, in 2002 [4]. Shortly after SARS-CoV was isolated and identified, similar SARS-like CoVs were detected in Himalayan palm civets and raccoon dogs; their nucleotide sequence was $99.8 \%$ homologous to that of SARS$\mathrm{CoV}$ isolated from humans [5].
SARS-CoV is a representative of the $\beta$-CoV group; it binds to a zinc peptidase angiotensin-converting enzyme 2 (ACE2), which is a surface molecule exploited by the virus to enter the host cell. ACE is present in various organs and tissues; it is an integral plasma membrane protein found in endothelial, specialized epithelial, neuroepithelial, nerve terminal, and reproductive system cells. The role of ACE is not limited to the regulation of cardiovascular system functions. It also participates in hematopoiesis and the metabolism of some bioactive peptides [6].

ACE2 is found in arterial and venous endothelial cells, smooth muscle cells of the arterial wall, the epithelium of the respiratory tract and the small intestine, and immune system cells. It is hypothesized that the inhibition of ACE2 expression in patients infected with SARS-CoV is implicated in the pathological changes to pulmonary tissue, causing severe pneumonia and acute respiratory failure.

Research studies on wild animals proved that SARSCoV could have originated in bats: Chinese horseshoe bats were found to harbor a SARS-like CoV with high nucleotide homology (87-92\%) to SARS-CoV isolated from humans. Palm civets and raccoon dogs are putative intermediate hosts for SARS-CoV amplification preceding its transmission to other animals through contact at a market. SARS-CoV is transmitted from human to human by respiratory droplets during close contact (airborne spread).

There is a proposition about the possibility of the fecal-oral transmission route for SARS-CoV-2 predicated on the fact that patients stricken by SARS or MERS during the past outbreaks often had gastrointestinal symptoms, such as diarrhea and abdominal pain, and SARS-CoV RNA was detected in the feces of $14.6 \%$ patients with SARS or MERS [7]. Some patients presented with fever and diarrhea before developing pronounced respiratory symptoms [8]. In vitro studies have demonstrated that MERS-CoV can infect and replicate in the intestinal epithelium of humans using dipeptidyl peptidase 4 as a receptor. In vivo studies have revealed that inflammation and epithelial degeneration in the small intestine can precede pneumonia in MERS, confirming that pulmonary MERS-CoVinduced infection can be secondary to the enteric infection [9].

According to some authors, the incubation period for SARS-CoV-2 varies between 2 and 11 days, being 5.2 days on average (95\% Cl 4.1-7.0) [10]; other researchers report that the incubation period lasts up to 14 days [11].

SARS-CoV can be excreted into the environment and transmitted by hand contact between patients and healthcare workers; this means that surfaces must be sanitized and the nose, mouth and eyes must be protected against the virus [12].

The ability of an infected individual to spread the virus to other people is inferred from the RO (basic reproduction number) value. For SARS-CoV, RO is about 3, i.e. a person infected with SARS-CoV will potentially infect 3 other people in a susceptible population. The average $\mathrm{RO}$ value for seasonal flu (swine flu, H1N1) is about 1.3 [13] (Table 1).

So far, no effective vaccine or medication against SARSCoV has been developed. The clinical management of patients with SARS includes supportive symptomatic treatment and prescription of broad-spectrum antimicrobials against secondary bacterial infection. Advanced age (upwards of 60 years), multimorbidity (diabetes mellitus, CVD, cancer, chronic obstructive pulmonary disease), and elevated lactate dehydrogenase are predictors of death in patients with SARSCoV infection. Some authors point to insignificant morbidity and mortality rates in children and adolescents in the past SARS outbreaks [14]. 
At the same time, preliminary data on 4,226 confirmed COVID-19 cases in the USA suggest high mortality in patients aged $\geq 85$ years (10-27\%). In patients aged 65-84 years, the case mortality rate ranged from 3 to $11 \%$; in patients aged 55-64 years, it was 1-3\%, whereas in patients aged 20-54 years, less than $1 \%$. No deaths were reported in patients aged $\leq$ 19 years. There were young patients among the hospitalized individuals. Deaths registered in the group of patients aged 20-64 years amounted to $20 \%$ of overall case mortality; in this age group, hospitalized patients aged 20-44 years made 20\% [15]

Currently, there is a paucity of published studies investigating risk factors and death predictors in patients with COVID-19. Starting on December 25,2019 through January 26,2020, a study was conducted in 201 patients with COVID-19 aged 43 to 60 years (the median age was 51), of whom $63.7 \%$ were men, revealing that $32.8 \%$ of the participants had a pre-existing condition. The median hospital stay was $13(10-16)$ days; $33 \%$ of the patients required mechanical ventilation; the median interval between admission to hospital and progression to SARS was 2 (1-4) days. Blood tests revealed that the majority of the patients had elevated lactate dehydrogenase (98\%), elevated C-reactive protein (85.6\%), elevated interleukin $6(48.8 \%)$, and elevated D-dimer (23.3\%). Age upwards of 65 years, neutrophilia, organ dysfunction, and coagulation dysfunction were associated with progression to acute respiratory distress syndrome (ARDS) and death. In the patients who developed ARDS, administration of methylprednisolone was associated with lower mortality (46\%), as compared to methylprednisolone-free treatment $(61.8 \%)$ (OR 0.38) [16]

\section{Clinical presentations of COVID-19}

The most prevalent COVID-19 symptoms include fever, cough, labored breathing (shortness of breath or rapid breathing). Myalgia, anorexia, nausea, malaise, sore throat, nasal congestion, and headache are less common. The symptoms can set in as early as 2 days after contact with an infected person or by day 14 following such contact. The viral load does not differ between symptomatic and asymptomatic patients, suggesting a possibility of transmission from an asymptomatic individual or a patient with mild symptoms to another person. The highest number of viral copies is detected in nasal swabs, as compared to throat swabs. The diagnosis of COVID-19 is confirmed by PCR. Mucosal specimens for PCR are collected either from the upper or the lower respiratory tracts. A case of COVID-19 is assumed to be confirmed if the laboratory test for the presence of SARS-CoV-2 RNA returns a positive result even in the absence of clinical symptoms. Point-of-care serological tests are expected to be available in the nearest future.

\section{Potential mechanisms underlying the effects of coronavirus infection on the cardiovascular system}

The danger of $\mathrm{ARI}$ lies surging mortality from chronic diseases during an epidemic, especially among patients with cardiovascular pathology. According to a systematic review which included 42 publications and 39 clinical studies and was published in 2009 patients were at heightened risk of myocardial infarction (OR 4.95; 95\% Cl 4.4-5.5) and stroke (OR 3.2; 95\% $\mathrm{Cl} 2.8-3.6)$ in the first few days following the onset of ARI; over time, this risk was gradually decreasing [17].

The hypothesis that influenza can provoke acute cardiovascular events and death was proposed in the 1930s. It was then that a link was noticed between the seasonal activity of flu viruses and higher mortality from all causes, including bronchopulmonary pathology, pulmonary TB, diabetes mellitus, organic heart disease, and hemorrhagic stroke [18].

In 2004, another study reported a vast array of lifethreatening clinical manifestations of coronavirus infection, including death from myocardial infarction (2 of 5 deaths); this unveiled the need for prompt treatment of CVD patients during a potential epidemic of a respiratory infection [19].

The lessons learnt from past epidemics caused by coronaviruses inspired a hypothesis that viral infections can provoke acute coronary syndrome, arrhythmias, heart failure, and thromboembolic complications resulting from the pronounced systemic inflammatory response combined with localized vascular inflammation.

In this respect, COVID-19 should not be an exception. It seems to affect the clinical course of pre-existing CVD and trigger development of life-threatening complications [20].

The severity of clinical manifestations, long- and shortterm cardiovascular effects of COVID-19, and the effects of specific treatment are yet to be researched. It should be noted that during flu epidemics the majority of patients die of cardiovascular complications and not of virus-induced pneumonia itself. Considering the extreme inflammatory load caused by COVID-19 and the available clinical data on other coronavirus-related infections, one can expect to see serious cardiovascular complications in patients with COVID-19; their prevalence and severity will probably be lower in outpatients than in hospitalized individuals.

In a recently published study [21], $73 \%$ of 41 inpatients with laboratory-confirmed COVID-19 were men and 32\% had pre-existing conditions, such as diabetes mellitus (20\%), arterial hypertension $(\mathrm{AH})(15 \%)$, and other CVD (15\%). The median age of the patients was 49 (41-58) years. Among the most common symptoms of COVID-19 were fever (98\%), cough $(76 \%)$, sputum production $(28 \%)$, myalgia or fatigue (44\%), headache (8\%), hemoptysis (5\%), and diarrhea (3\%). Lymphopenia was observed in $63 \%$ of the patients, shortness of breath, in $55 \%$. The median time from the onset of symptoms to developing shortness of breath was $8(5-13)$ days. Some of the complications included ARDS (29\%) and acute cardiac injury (12\%).

Another study conducted in 1,099 in- and outpatients with laboratory-confirmed COVID-19 (median age of 47 years; $42 \%$ women) found that the most common pre-existing conditions were $\mathrm{AH}$ (14.9\%), diabetes mellitus (7.4\%) and CAD (2.5\%). ARDS (3.4\%) and shock (1.1\%) were the most severe complications [22].

In most patients with myocarditis, viral infection and the immune response to it are the root causes of inflammation. The leading mechanisms underlying myocardial injury in the acute phase of myocarditis are invasion of cardiomyocytes by viral particles that have tropism for myocardial tissue, the direct

Table 1. Characteristics of coronaviruses

\begin{tabular}{|l|c|c|c|c|c|}
\hline Coronavirus species & Receptor & Incubation period (days) & R0 & Co-existing CVD, \% & Mean case fatality rate, $\%$ \\
\hline SARS-CoV & ACE2 & $2-11$ & 3 & 10 & 10 \\
\hline SARS-CoV-2 & ACE2 & $2-14$ & $2-3$ & от 3.4 $4^{\star}$ до $40^{\star \star}$ & $0.7-8^{\star \star \star}$ \\
\hline
\end{tabular}

Note: * — overall rates; ${ }^{\star *}$ — in hospitalized patients; ${ }^{\star \star \star}$ — depending on time, geographical area and medical help available. 


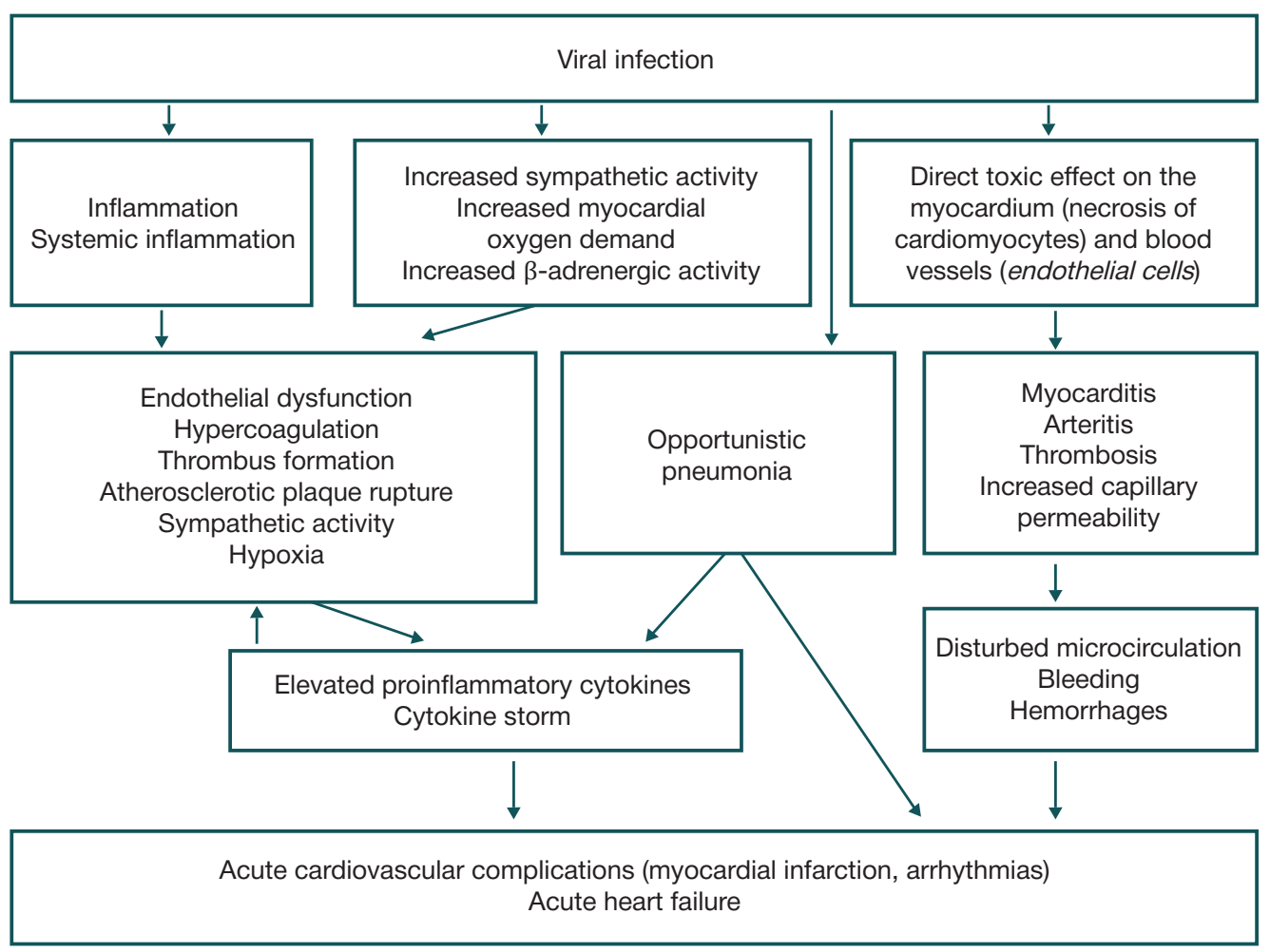

Fig. 1. Effects of viral infection on the cardiovascular system and the myocardium

cytopathic effect of the virus and the activation of nonspecific mechanisms of antiviral defense implemented by macrophages and NK cells. Activated macrophages and other immune cells start to produce chemokines and thus recruit $T$ and $B$ cells to the inflammation site. The recruited cells drive cell-mediated cytolysis and launch production of antiviral antibodies, thus triggering the mechanism of cardiomyocyte apoptosis, which eventually results in systolic heart failure.

The findings of sporadic autopsies and reports of severe myocarditis with left ventricular systolic dysfunction after a past COVID-19 infection suggest that the myocardium gets infiltrated by interstitial mononuclear inflammatory cells [23]. A study of cardiac biomarkers points to the high prevalence of myocardial injury in hospitalized patients; this condition is an important prognostic factor for COVID-19 [24].

Myocarditis is a polyetiological disease. It can be caused by viral or bacterial agents, as well as by non-infectious factors. Over $50 \%$ of myocarditis cases are associated with a viral infection. Parvovirus B19, Coxsackie A and B enteroviruses, $\mathrm{ECHO}$-viruses, rubella virus, adenoviruses, human herpesvirus 6, Epstein-Barr virus, influenza virus, cytomegalovirus, etc. have high tropism for cardiomyocytes [25].

Clinical presentations of myocarditis are diverse and nonspecific. The diagnosis relies on a triad of medical history findings: the acute onset of the disease, the established link between the onset or exacerbation of symptoms/ arrhythmias and the infection, and the time elapsed from the infection ( $\leq 1$ year). Additional criteria include systemic immune manifestations, the combination of arrhythmia and conductivity disorders, and the positive effect of prescribed steroids [26].

In a recently published paper, researchers describe the results of observation of 416 inpatients with COVID-19; 57 (13.7\%) of the patients eventually died [27]. Of them, $10.6 \%$ had CAD; $5.3 \%$, cerebrovascular disease; $4.1 \%$, heart failure; one in 5 patients had elevated high-sensitivity troponin levels. Patients with elevated troponin were of advanced age, had more comorbidities, lymphopenia, higher white cell count and higher levels of atrial natriuretic peptide, C-reactive protein and procalcitonin than those with normal troponin levels. Patients with acute inflammatory heart disease developed ARDS more often than those without acute cardiac condition $(58.5 \%$ vs $14.7 \%$, respectively; $p<0.001$ ); the proportion of deaths in this group was also higher (51.2\% vs $4.5 \%$, respectively; $p<0.001)$. Multivariate analysis confirmed that acute heart failure (OR 4.26) and ARDS (OR 7.89) were predictors of poor outcome in patients with COVID-19.

Similar results are reported by other authors [24], who found that $27.8 \%$ of 187 included patients with confirmed COVID-19 had developed acute cardiovascular complications resulting in cardiac dysfunction and arrhythmias; a combination of cardiovascular complications with elevated high-sensitivity troponin was associated with high mortality.

Although pathophysiological mechanisms underlying myocardial injury in patients with COVID-19 are heavily understudied, there is evidence that the SARS-CoV genome is found in the myocardium of $35 \%$ of patients with SARS. These findings increase the probability of direct damage to cardiomyocytes by the virus. SARS-CoV-2 might utilize the same mechanism of action as SARS-CoV as these two species are genetically close, although not identical. The close correlation between elevated high-sensitivity troponin and C-reactive protein levels implies the inflammatory origin of myocardial injury in the progressive disease phase. As viral particles spread along the respiratory tract and invade host cells, they may trigger a cytokine storm ensuing from the imbalance in Th1 and Th2 production and a cascade of immune reactions that lead to myocardial injury. In the setting of infection, secretion of cytokines can cause a reduction in coronary blood flow and oxygen supply, atherosclerotic plaques destabilization and formation of microclots (Fig. 1).

Myocarditis is often manifested as arrhythmias, progressive heart failure and sudden cardiac arrest that can occur at any stage of the disease. 


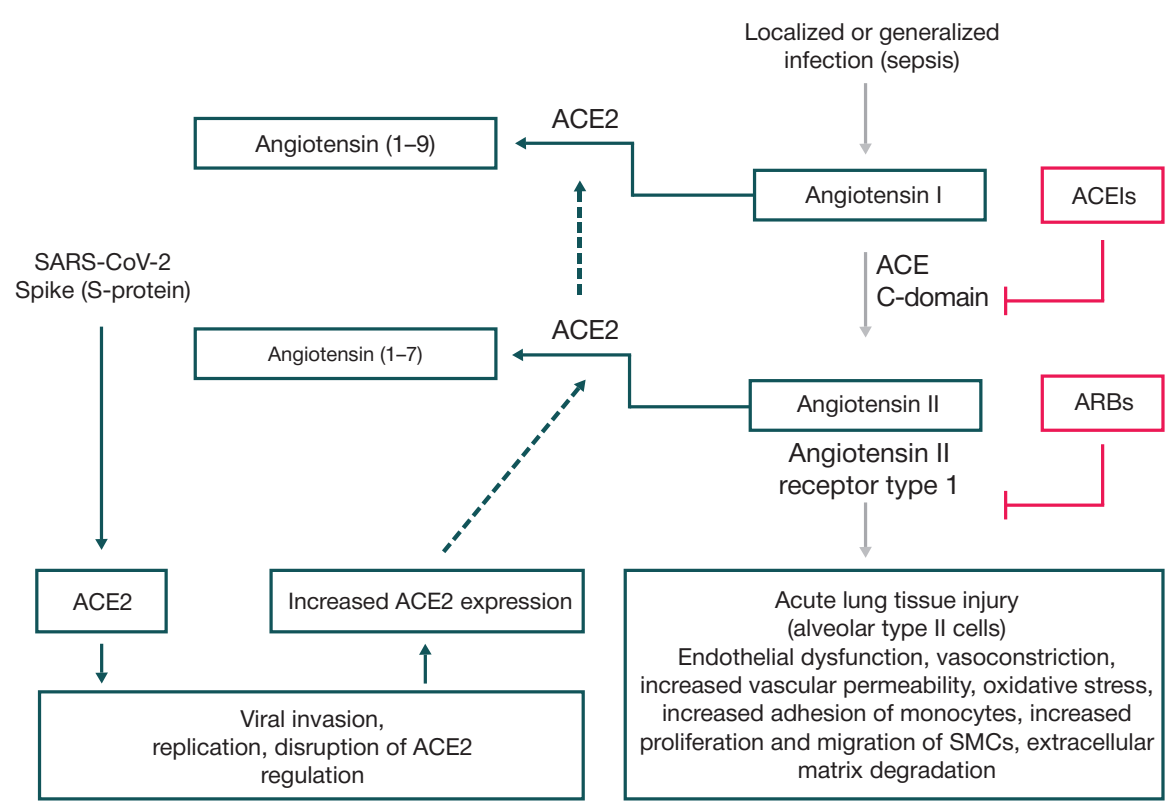

Fig. 2. Interactions between SARS-CoV-2 and the renin-angiotensin-aldosterone system. Interaction between SARS-CoV-2 and the renin-angiotensin-aldosterone system. Invasion of host cells (alveolar type II cells, in particular) by SARS-CoV-2 occurs through the binding of the virus to the functional domain of ACE2. ACE2 expression changes following endocytosis of the viral complex. This results in the accumulation of a potent vasoconstrictor angiotensin II and, possibly, mitigates the vasodilator effect of angiotensin (1-7). Local activation of the renin-angiotensin-aldosterone system can mediate damage to the lungs in response to viral infection, whereas increased ACE2 expression can aggravate pulmonary damage in patients with COVID-19. ACE2 converts angiotensin I to angiotensin (1-9) (its functions are being studied) and angiotensin II to angiotensin (1-7). This process is accompanied by inactivation of angiotensin II and synthesis of angiotensin (1-7); the latter stimulates vasodilation, reduces oxidative stress and fibrosis. ACE - angiotensin-converting enzyme; ACEI — ACE inhibitors; ARB — angiotensin II receptor blockers; SMC - smooth muscle cells. ACE angiotensin-converting enzyme; ACEls - ACE inhibitors; ARBs — angiotensin II receptor blockers; SMCs — smooth muscle cells

Among the first symptoms of myocarditis are malaise, fatigue, myalgia, and sometimes low-grade temperature caused by the inflammatory response to the virus but not by myocardial injury itself. Other manifestations of myocarditis include sudden cardiac arrest due to ventricular tachycardia or ventricular fibrillation following damage to the conducting system of the heart, thromboembolism, syncope, cardiogenic shock, and acute heart failure. The first clinical symptoms can set in at the onset of ARI or a few days after its onset.

There are a number of obstacles complicating the diagnosis of viral myocarditis. The primary diagnostic criterion for myocarditis is the established link between cardiac symptoms and a past infection and the signs of inflammation. The diagnosis can be facilitated by a full medical examination of the patient, which includes clinical, laboratory and instrumental tests, and by endomyocardial biopsy performed to rule out the inflammatory nature of myocardial injury [28].

Unfortunately, currently there is no substantiated evidence about the efficacy of existing antivirals and vaccines against COVID-19. Patients with pre-existing CVD are at high risk of complications, a more severe course of the disease and poor outcomes; therefore, CVD patients with COVID-19 should be stratified depending on their primary condition (CVD) and its severity in order to decide on the treatment strategy. Electrocardiography and cardiac biomarker tests (NT-proBNP) can be employed to control the condition of the patient and the course of treatment.

There is a lot of controversy over whether patients infected with a coronavirus should continue angiotensin-converting enzyme inhibitors (ACE inhibitors) and angiotensin II receptor blockers (ARBs). The fears are predicated on the fact that the protease domain of ACE2 is a potential target for SARS-CoV and SARS-CoV-2 and that increased expression of ACE2 can aggravate damage to the lungs in patients with COVID-19 (Fig. 2) (adapted from [29]).

ACE2 exists in 2 forms: as a structural transmembrane protein with an extracellular domain, which serves as a target for the S protein of SARS-CoV-2, and as a soluble circulating form. Invasion of host cells (alveolar type II cells in the first place) by SARS-CoV-2 occurs through the binding of the virus to the protease domain of ACE2. Upon endocytosis of the viral complex, ACE2 expression changes, causing increased accumulation of a potent vasoconstrictor angiotensin II. The local activation of the renin-angiotensin-aldosterone system (RAAS) can mediate damage to the lungs in response to viral infection [30].

Angiotensin (1-7) is a substrate for the N-domain of ACE; it suppresses the activity of ACE C-domain and limits pressor and vasoconstrictive effects of angiotensin II.

The role of this process in the development of COVID-19related complications and the effects of the possible modulation of the ACE2 receptor are not fully clear and expected to be investigated in the clinical trials of human recombinant ACE2 (NCT04287686) and other therapeutic agents.

In the group of patients with COVID-19 and high troponin levels, the duration of therapy with ACEls/ARBs prescribed for pre-existing CVD did not have any effect on mortality [22]. In another study, a positive effect of ACEls/ARBs was observed in patients with viral pneumonias because the drugs significantly reduced inflammation and secretion of proinflammatory cytokines triggered in response to infection [31]. The beneficial effect of ACEls/ARBs might be associated with the compensatory increase in ACE2 production. So far, there are no data on the use of ACEIs/ARBs in patients with COVID-19, which raises the need for further large-scale clinical studies.

At present, the experts from the European Society of Cardiology [32], the American Heart Association [33] and the Russian Society of Cardiology [34] recommend that patients with COVID-19 who had indications for ACEls/ARBs and were taking these drugs before the infection should continue them because there is no evidence of their inefficacy in such patients.

Also, there are no experimental or clinical data demonstrating positive or negative effects of ACEIs/ARBs or other RAAS antagonists in patients with COVID-19, as well as in patients 
Table 2. A non-exhaustive list of clinical trials of drugs for the prevention and treatment of COVID-19

\begin{tabular}{|l|c|c|c|}
\hline \multicolumn{1}{|c|}{ Drug } & Start date & Estimated completion date & $\begin{array}{c}\text { Trial ID at } \\
\text { ClinicalTrials.gov }\end{array}$ \\
\hline Remdesivir & February 21, 2020 & April 1, 2023 & NCT04280705 \\
\hline Human recombinant ACE2 & February 2020 & April 2020 & NCT04287686 \\
\hline Remdesivir & March 2020 & May 2020 & NCT04292899 \\
\hline $\begin{array}{l}\text { Injections and infusions of the LV-SMENP-DS and antigen-specific } \\
\text { cytotoxic T cell vaccines }\end{array}$ & February 24, 2020 & December 31, 2024 & NCT04276896 \\
\hline Fingolimod & February 22, 2020 & July 1, 2020 & NCT04280588 \\
\hline Human mesenchymal stem cells & February 24, 2020 & February 1, 2021 & NCT04293692 \\
\hline Carrimycin & February 23, 2020 & February 28, 2021 & NCT04286503 \\
\hline Methylprednisolone & February 14, 2020 & May 30, 2020 & NCT04273321 \\
\hline Washed microbiota transplantation & February 2, 2020 & April 16, 2020 & NCT04251767 \\
\hline Losartan & March 16, 2020 & April 1, 2021 & NCT04312009 \\
\hline 2019-nCoV vaccine (mRNA-1273) & March 3, 2020 & June 1, 2021 & NCT04283461 \\
\hline Lopinavir / ritonavir tablets combined with xiyanping injection & March 14, 2020 & April 14, 2021 & NCT04295551 \\
\hline
\end{tabular}

with COVID-19 and a history of CVD. If a patient with CVD is infected with COVID-19, the treatment strategy should account for their overall symptoms and hemodynamics.

RAAS activation plays a crucial role in the pathogenesis of many CVD. Long-term effects of increased renin and angiotensin II production and the activity of the sympathetic nervous system include left ventricular hypertrophy, dyslipidemia, arrythmias, hypercoagulation, endothelial dysfunction, insulin resistance, and metabolic syndrome. ACEls and ARBs that have been studied and successfully used in the clinical setting for many years are first-choice drugs for treating chronic heart failure, $\mathrm{AH}$, renal disorders, and diabetes mellitus [35, 36].

The ACE2-dependent entry of SARS-CoV-2 into the host cell can be blocked by camostat mesylate, the inhibitor of serine protease TMPRSS2 used by SARS-CoV-2 for S protein priming. Camostat mesylate is a promising candidate for further trials [37].

Among the antivirals for treating flu, oseltamivir does not have any effect on SARS-CoV-2 although preliminary studies have demonstrated some positive effects of favipiravir. Table 2 features a few drugs which are now in clinical trials or being considered as candidates for clinical trials in patients with COVID-19.

\section{CONCLUSIONS}

The data collected so far suggest a high prevalence of comorbidities in middle-aged and old patients with COVID-19. The most common cardiovascular conditions are $\mathrm{AH}$ (about 15\%), diabetes mellitus (7.4-20\%) and CAD (about 2.5\%). Patients with COVID-19 and a pre-existing cardiovascular pathology are at high risk of developing ARDS, shock and death. Acute cardiac failure and ARDS are regarded as predictors of poor outcomes in patients with COVID-19.

It is crucial to study different aspects of screening, diagnostics, clinical manifestations, prevention and management of patients with COVID-19. As the infection spreads and more data are accumulated, risk factors for cardiovascular complications should be thoroughly investigated.

Perhaps, creating a registry of patients with COVID-19 and systemic reporting of clinical symptoms and cardiovascular and other complications will help to elucidate the characteristics of the infected patients, develop approaches to the treatment and prevention and design a risk model for predicting complications.

\section{References}

1. Fauci AS, Lane HC, Redfield RR. Covid-19: navigating the uncharted. N Engl J Med. 2020. DOI: 10.1056/NEJMe2002387.

2. Cowan LT, Lutsey PL, Pankow JS, Matsushita K, Ishigami J, Lakshminarayan K. Inpatient and outpatient infection as a trigger of cardiovascular disease: the ARIC study. J Am Heart Assoc. 2018; 7 (22): e009683-e009683. DOI: 10.1161/ JAHA.118.009683

3. Su S, Wong G, Shi W, et al. Epidemiology, genetic recombination, and pathogenesis of coronaviruses. Trends Microbiol. 2016; 24 (6): 490-502. DOI: 10.1016/j.tim.2016.03.003.

4. Song HD, Tu CC, Zhang GW, Wang SY, Zheng K, et al. Crosshost evolution of severe acute respiratory syndrome coronavirus in palm civet and human. Proceedings of the National Academy of Sciences. 2005; 102 (7) 2430-2435; DOI: 10.1073/ pnas.0409608102

5. Berry M, Gamieldien J, Fielding BC. Identification of new respiratory viruses in the new millennium. Viruses. 2015; 7 (3): 996-1019. DOI: 10.3390/v7030996.

6. Nagai T, Nitta K, Kanasaki M, Kova D, Kanasaki K. The biological significance of angiotensin-converting enzyme inhibition to combat kidney fibrosis. Clin Exp Nehrol. 2015; 19 (1): 65-74.
7. Yeo C, Kaushal S, Yeo D. Enteric involvement of coronaviruses: is faecal-oral transmission of SARS-CoV-2 possible? Lancet Gastroenterol Hepatol. 2020; 5 (4): 335-7. DOI: 10.1016/S24681253(20)30048-0

8. Assiri A, Al-Tawfiq JA, Al-Rabeeah AA, et al. Epidemiological, demographic, and clinical characteristics of 47 cases of Middle East respiratory syndrome coronavirus disease from Saudi Arabia: a descriptive study. Lancet Infect Dis. 2013; (13): 752-61.

9. Zhou J, Li C, Zhao G, et al. Human intestinal tract serves as an alternative infection route for Middle East respiratory syndrome coronavirus. Sci Adv. 2017; (3): eaao4966.

10. Chan JF-W, Yuan S, Kok K-H, et al. A familial cluster of pneumonia associated with the 2019 novel coronavirus indicating person-to-person transmission: a study of a family cluster. Lancet. 2020; 395 (10223): 514-23. DOI: 10.1016/S0140-6736(20)30154-9.

11. Backer JA, Klinkenberg D, Wallinga J. Incubation period of 2019 novel coronavirus (2019-nCoV) infections among travellers from Wuhan, China, 20-28 January 2020. Euro Surveill. 2020; 25 (5): 2000062. DOI: 10.2807/1560-7917.ES.2020.25.5.2000062.

12. Otter JA, Donskey C, Yezli S, Douthwaite S, Goldenberg SD, Weber DJ. Transmission of SARS and MERS coronaviruses and 
influenza virus in healthcare settings: the possible role of dry surface contamination. J Hosp Infect. 2016; 92 (3): 235-50. DOl: 10.1016/j.jhin.2015.08.027.

13. Madjid M, Safavi-Naeini P, Solomon SD, Vardeny O. Potential Effects of Coronaviruses on the Cardiovascular System: A Review. JAMA Cardiol. Published online March 27, 2020. DOI: 10.1001/ jamacardio.2020.1286.

14. Berry M, Gamieldien J, Fielding BC. Identification of new respiratory viruses in the new millennium. Viruses. 2015; 7 (3): 996-1019. DOI: 10.3390/v7030996.

15. US Centers for Disease Control and Prevention COVID-19 Response Team. Severe Outcomes Among Patients with Coronavirus Disease 2019 (COVID-19): United States, February 12-March 16, 2020. MMWR Morb Mortal Wkly Rep. Published online March 18, 2020. DOI: 10.15585/mmwr.mm6912e2.

16. Wu C, Chen X, Cai Y, Xia J, Zhou X, et al. Risk factors associated with acute respiratory distress syndrome and death in patients with coronavirus disease 2019 pneumonia in Wuhan, China JAMA Intern Med. 2020 Mar 13. https://doi.org/10.1001/ jamainternmed.2020.0994.

17. C. Warren-Gash, et al. Influenza as a trigger for acute myocardial infarction or death from cardiovascular disease: a systematic review. Lancet Infect Dis. 2009; 9 (10): 601-10.

18. Collins S. Excess mortality from causes other than influenza and pneumonia during influenza epidemics. Public Health Rep. 1932; (47): 2159-89.

19. Peiris JS, Chu CM, Cheng VC, et al. HKU/UCH SARS Study Group. Clinical progression and viral load in a community outbreak of coronavirus-associated SARS pneumonia: a prospective study. Lancet. 2003; 361 (9371): 1767-72. DOI: 10.1016/S01406736(03)13412-5.

20. Kwong JC, Schwartz KL, Campitelli MA, et al. Acute myocardia infarction after laboratory-confirmed influenza infection. N Engl $J$ Med. 2018; 378 (4): 345-53. DOI: 10.1056/NEJMoa1702090.

21. Huang $C$, Wang $Y, L i X$, et al. Clinical features of patients infected with 2019 novel coronavirus in Wuhan, China. Lancet. 2020; 395 (10223): 497-506. DOI: 10.1016/S0140-6736(20)30183-5.

22. Guan WJ, Ni ZY, Hu Y, et al. China Medical Treatment Expert Group for Covid-19. Clinical characteristics of coronavirus disease 2019 in China. N Engl J Med. 2020. DOI: 10.1056/ NEJMoa2002032.

23. Inciardi RM, Lupi L, Zaccone G, et al. Cardiac involvement 1 with coronavirus 2019 (COVID-19) infection. JAMA Cardiol. 2020. DOl: 10.1001/jamacardio.2020.1096

24. Guo T, Fan Y, Chen M, et al. Association of cardiovascular disease and myocardial injury with outcomes of patients hospitalized with 2019-coronavirus disease (COVID-19). JAMA Cardiol. Published online March 27, 2020. DOI: 10.1001/ jamacardio.2020.1017.

25. Blagova OV, Nedostup AV. Contemporary masks of the myocarditis (from clinical signs to diagnosis. Russian Journal of Cardiology. 2014; (5): 13-22. https://doi.org/10.15829/15604071-2014-5-13-22. Russian

26. Blagova OV, Nedostup AV, Kogan EA, Sedov VP, Donnikov AV,
Kadochnikova W, et al. DCMP as a clinical syndrome: results of nosological diagnostics with myocardial biopsy and differentiated treatment in virus-positive and virus-negative patiens. Russian Journal of Cardiology. 2016; (1): 7-19. https://doi. org/10.15829/1560-4071-2016-1-7-19. Russian.

27. Shi S, Qin M, Shen B, et al. Cardiac injury in patients with corona virus disease 2019. JAMA Cardiol. Published online March 25, 2020. DOI: 10.1001/jamacardio.2020.0950.

28. Cooper L, Baughman K, Feldman A, Frustaci A, Jessup M, Kuhl U, et al. The role of endomyocardial biopsy in the management of cardiovascular disease: a scientific statement from the American Heart Association, the American College of Cardiology, and the European Society of Cardiology. Endorsed by the Heart Failure Society of America and the Heart Failure Association of the European Society of Cardiology. Journal of the American College of Cardiology. 2007; 50 (19): 1914-31.

29. Vaduganathan M, Vardeny O, Michel M, McMurray J, Pfeffer M, Solomon S. Renin-Angiotensin-Aldosterone System Inhibitors in Patients with Covid-19. March 30, 2020; DOI: 10.1056/ NEJMsr2005760

30. Bavishi C, Maddox TM, Messerli FH. Coronavirus Disease 2019 (COVID-19) Infection and Renin Angiotensin System Blockers. JAMA Cardiol. Published online April 03, 2020. DOI: 10.1001/ jamacardio.2020.1282

31. Henry C, Zaizafoun M, Stock E, Ghamande S, Arroliga AC, White HD. Impact of angiotensin-converting enzyme inhibitors and statins on viral pneumonia. Proc (Bayl Univ Med Cent). 2018; 31 (4): 41923. DOI: $10.1080 / 08998280.2018 .1499293$

32. de Simone G. Position Statement of the ESC Council on Hypertension on ACE-Inhibitors and Angiotensin Receptor Blockers. https://www.escardio.org/Councils/Council-onHypertension-(CHT)/News/position-statement-of-the-esccouncil-on-hypertension-on-ace-inhibitors-and-ang.

33. HFSA/ACC/AHA Statement Addresses Concerns Re: Using RAAS Antagonists in COVID-19. https://www.acc.org/latest-incardiology/articles/2020/03/17/08/59/hfsa-acc-aha-statementaddresses-concerns-re-using-raas-antagonists-in-covid-19.

34. Shlyakho EV, Konradi AO, Arutyunov GP, Arutyunov AG, Bautin AE, Boytsov SA, et al. Guidelines for the diagnosis and treatment of circulatory diseases in the context of the COVID-19 pandemic. Russian Journal of Cardiology. 2020; 25 (3): 3801. DOI: 10.15829/1560-4071-2020-3-3801. Russian.

35. Halliday BP, Wassall R, Lota AS, et al. Withdrawal of pharmacological treatment for heart failure in patients with recovered dilated cardiomyopathy (TRED-HF): an open-label, pilot, randomised trial. Lancet. 2019; (393): 61-73.

36. Thomsen M, Lewinter C, Køber L. Varying effects of recommended treatments for heart failure with reduced ejection fraction: metaanalysis of randomized controlled trials in the ESC and ACCF/ AHA guidelines. ESC Heart Failure. 2016; (3): 235-44.

37. Hoffmann M, Kleine-Weber H, Schroeder S, et al. SARS-CoV-2 cell entry depends on ACE2 and TMPRSS2 and is blocked by a clinically proven protease inhibitor. Cell. 2020; (181): 1-10. DOI: 10.1016/j.cell.2020.02.052.

\section{Литература}

1. Fauci AS, Lane HC, Redfield RR. Covid-19: navigating the uncharted. N Engl J Med. 2020. DOI: 10.1056/NEJMe2002387.

2. Cowan LT, Lutsey PL, Pankow JS, Matsushita K, Ishigami J, Lakshminarayan K. Inpatient and outpatient infection as a trigger of cardiovascular disease: the ARIC study. J Am Heart Assoc. 2018; 7 (22): e009683-e009683. DOl: 10.1161/ JAHA.118.009683

3. Su S, Wong G, Shi W, et al. Epidemiology, genetic recombination, and pathogenesis of coronaviruses. Trends Microbiol. 2016; 24 (6): 490-502. DOI: 10.1016/j.tim.2016.03.003.

4. Song HD, Tu CC, Zhang GW, Wang SY, Zheng K, et al. Crosshost evolution of severe acute respiratory syndrome coronavirus in palm civet and human. Proceedings of the National Academy

of Sciences. 2005; 102 (7) 2430-2435; DOI: 10.1073/ pnas.0409608102.

5. Berry M, Gamieldien J, Fielding BC. Identification of new respiratory viruses in the new millennium. Viruses. 2015; 7 (3): 996-1019. DOI: 10.3390/v7030996.

6. Nagai T, Nitta K, Kanasaki M, Kova D, Kanasaki K. The biological significance of angiotensin-converting enzyme inhibition to combat kidney fibrosis. Clin Exp Nehrol. 2015; 19 (1): 65-74.

7. Yeo C, Kaushal S, Yeo D. Enteric involvement of coronaviruses: is faecal-oral transmission of SARS-CoV-2 possible? Lancet Gastroenterol Hepatol. 2020; 5 (4): 335-7. DOI: 10.1016/S24681253(20)30048-0.

8. Assiri A, Al-Tawfiq JA, Al-Rabeeah AA, et al. Epidemiological, 
demographic, and clinical characteristics of 47 cases of Middle East respiratory syndrome coronavirus disease from Saudi Arabia: a descriptive study. Lancet Infect Dis. 2013; (13): 752-61.

9. Zhou J, Li C, Zhao G, et al. Human intestinal tract serves as an alternative infection route for Middle East respiratory syndrome coronavirus. Sci Adv. 2017; (3): eaao4966.

10. Chan JF-W, Yuan S, Kok K-H, et al. A familial cluster of pneumonia associated with the 2019 novel coronavirus indicating person-to-person transmission: a study of a family cluster. Lancet. 2020; 395 (10223): 514-23. DOI: 10.1016/S0140-6736(20)30154-9.

11. Backer JA, Klinkenberg D, Wallinga J. Incubation period of 2019 novel coronavirus (2019-nCoV) infections among travellers from Wuhan, China, 20-28 January 2020. Euro Surveill. 2020; 25 (5): 2000062. DOI: 10.2807/1560-7917.ES.2020.25.5.2000062.

12. Otter JA, Donskey C, Yezli S, Douthwaite S, Goldenberg SD, Weber DJ. Transmission of SARS and MERS coronaviruses and influenza virus in healthcare settings: the possible role of dry surface contamination. J Hosp Infect. 2016; 92 (3): 235-50. DOI: 10.1016/j.jhin.2015.08.027.

13. Madjid M, Safavi-Naeini P, Solomon SD, Vardeny O. Potentia Effects of Coronaviruses on the Cardiovascular System: A Review. JAMA Cardiol. Published online March 27, 2020. DOI: 10.1001/ jamacardio.2020.1286.

14. Berry $M$, Gamieldien J, Fielding BC. Identification of new respiratory viruses in the new millennium. Viruses. 2015; 7 (3): 996-1019. DOI: 10.3390/v7030996.

15. US Centers for Disease Control and Prevention COVID-19 Response Team. Severe Outcomes Among Patients with Coronavirus Disease 2019 (COVID-19): United States, February 12-March 16, 2020. MMWR Morb Mortal Wkly Rep. Published online March 18, 2020. DOI: 10.15585/mmwr.mm6912e2.

16. Wu C, Chen X, Cai Y, Xia J, Zhou X, et al. Risk factors associated with acute respiratory distress syndrome and death in patients with coronavirus disease 2019 pneumonia in Wuhan, China JAMA Intern Med. 2020 Mar 13. https://doi.org/10.1001/ jamainternmed.2020.0994.

17. C. Warren-Gash, et al. Influenza as a trigger for acute myocardial infarction or death from cardiovascular disease: a systematic review. Lancet Infect Dis. 2009; 9 (10): 601-10.

18. Collins $S$. Excess mortality from causes other than influenza and pneumonia during influenza epidemics. Public Health Rep. 1932; (47): 2159-89.

19. Peiris JS, Chu CM, Cheng VC, et al. HKU/UCH SARS Study Group. Clinical progression and viral load in a community outbreak of coronavirus-associated SARS pneumonia: a prospective study. Lancet. 2003; 361 (9371): 1767-72. DOI: 10.1016/S01406736(03)13412-5.

20. Kwong JC, Schwartz KL, Campitelli MA, et al. Acute myocardia infarction after laboratory-confirmed influenza infection. N Engl Med. 2018; 378 (4): 345-53. DOI: 10.1056/NEJMoa1702090.

21. Huang $C$, Wang $Y, L i X$, et al. Clinical features of patients infected with 2019 novel coronavirus in Wuhan, China. Lancet. 2020; 395 (10223): 497-506. DOI: 10.1016/S0140-6736(20)30183-5.

22. Guan WJ, Ni ZY, Hu Y, et al. China Medical Treatment Expert Group for Covid-19. Clinical characteristics of coronavirus disease 2019 in China. N Engl J Med. 2020. DOl: 10.1056/ NEJMoa2002032.

23. Inciardi RM, Lupi L, Zaccone G, et al. Cardiac involvement 1 with coronavirus 2019 (COVID-19) infection. JAMA Cardiol. 2020. DOI: 10.1001/jamacardio.2020.1096.

24. Guo T, Fan $\mathrm{Y}$, Chen M, et al. Association of cardiovascular disease and myocardial injury with outcomes of patients hospitalized with 2019-coronavirus disease (COVID-19). JAMA Cardiol. Published online March 27, 2020. DOI: 10.1001/jamacardio.2020.1017.

25. Благова О. В., Недоступ А. В. Современные маски миокардита (от клинических синдромов к диагнозу). Российский кардиологический журнал. 2014; (5): 13-22. https://DOI. org/10.15829/1560-4071-2014-5-13-22.

26. Благова О. В., Недоступ А. В., Коган Е. А., Седов В. П., Донников А. Е., Кадочникова В. В., и др. ДКМП как клинический синдром: результаты нозологической диагностики с применением биопсии миокарда и дифференцированного лечения у вирус- позитивных и вирус-негативных больных. Российский кардиологический журнал. 2016; (1): 7-19. https://doi.org/10.15829/1560-4071-2016-1-7-19.

27. Shi S, Qin M, Shen B, et al. Cardiac injury in patients with corona virus disease 2019. JAMA Cardiol. Published online March 25 , 2020. DOI: 10.1001/jamacardio.2020.0950

28. Cooper L, Baughman K, Feldman A, Frustaci A, Jessup M, Kuhl U, et al. The role of endomyocardial biopsy in the management of cardiovascular disease: a scientific statement from the American Heart Association, the American College of Cardiology, and the European Society of Cardiology. Endorsed by the Heart Failure Society of America and the Heart Failure Association of the European Society of Cardiology. Journal of the American College of Cardiology. 2007; 50 (19): 1914-31.

29. Vaduganathan M, Vardeny O, Michel M, McMurray J, Pfeffer $M$, Solomon S. Renin-Angiotensin-Aldosterone System Inhibitors in Patients with Covid-19. March 30, 2020; DOI: 10.1056/ NEJMsr2005760.

30. Bavishi C, Maddox TM, Messerli FH. Coronavirus Disease 2019 (COVID-19) Infection and Renin Angiotensin System Blockers. JAMA Cardiol. Published online April 03, 2020. DOI: 10.1001/ jamacardio.2020.1282

31. Henry C, Zaizafoun M, Stock E, Ghamande S, Arroliga AC, White HD. Impact of angiotensin-converting enzyme inhibitors and statins on viral pneumonia. Proc (Bayl Univ Med Cent). 2018; 31 (4): 41923. DOI: $10.1080 / 08998280.2018 .1499293$

32. de Simone G. Position Statement of the ESC Council on Hypertension on ACE-Inhibitors and Angiotensin Receptor Blockers. https://www.escardio.org/Councils/Council-onHypertension-(CHT)/News/position-statement-of-the-esccouncil-on-hypertension-on-ace-inhibitors-and-ang.

33. HFSA/ACC/AHA Statement Addresses Concerns Re: Using RAAS Antagonists in COVID-19. https://www.acc.org/latest-incardiology/articles/2020/03/17/08/59/hfsa-acc-aha-statementaddresses-concerns-re-using-raas-antagonists-in-covid-19.

34. Шляхто Е. В., Конради А. О., Арутюнов Г. П., Арутюнов А. Г., Баутин А. Е., Бойцов С. А., и др. Руководство по диагностике и лечению болезней системы кровообращения в контексте пандемии ООУЮ-19. Российский кардиологический журнал. 2020; 25 (3): 3801. DOI: 10.15829/1560-4071-2020-3-3801.

35. Halliday BP, Wassall R, Lota AS, et al. Withdrawal of pharmacological treatment for heart failure in patients with recovered dilated cardiomyopathy (TRED-HF): an open-label, pilot, randomised trial. Lancet. 2019; (393): 61-73.

36. Thomsen M, Lewinter $C$, Køber $L$. Varying effects of recommended treatments for heart failure with reduced ejection fraction: metaanalysis of randomized controlled trials in the ESC and ACCF/ AHA guidelines. ESC Heart Failure. 2016; (3): 235-44.

37. Hoffmann M, Kleine-Weber H, Schroeder S, et al. SARS-CoV-2 cell entry depends on ACE2 and TMPRSS2 and is blocked by a clinically proven protease inhibitor. Cell. 2020; (181): 1-10. DOI: 10.1016/j.cell.2020.02.052. 